\title{
Graft aneurysm as long-term complication of a polyester prosthesis - short review based on a systematic review of literature
}

\author{
Barth U', Wasseroth $\mathrm{K}^{1}$, Meyer $\mathrm{F}^{2 *}$
}

'Center of Vascular medicine, Aschersleben / Schönebeck (certified by the "German Society for Vascular Surgery and Vascular Medicine"), AMEOS Hospital, Schönebeck, Germany

${ }^{2}$ Dept. of General, Abdominal, Vascular and Transplant Surgery, University Hospital at Magdeburg, Magdeburg, Germany

\section{Article Info}

\section{Article Notes}

Received: May 09, 2018

Accepted: June 14, 2018

\section{*Correspondence:}

Prof. Dr. med. F. Meyer, Department of General, Abdominal, Vascular and Transplant Surgery, University Hospital, Leipziger Strasse 44, 39120 Magdeburg, Germany; Telephone: 0049 391-67 15500, Fax: 004939167 15570; Email: frank.meyer@med.ovgu.de

C 2018 Meyer F. This article is distributed under the terms of the Creative Commons Attribution 4.0 International License.

\section{ABSTRACT}

Introduction: A material-associated non-anastomotic aneurysm after previous use of a vascular prosthesis for arterial reconstruction mostly in peripheral arterial occlusion disease (PAOD) is considered a rare but serious complication.

Aim \& method: The aim of the compact short review was - based on selected topic-related references from the medical literature as - to describe the rare finding of prosthetic non-anastomotic aneurysm and its diagnosisspecific care.

Results (complex patient- \& clinical finding-associated corner points): Twenty articles were finally evaluated out of initially 321 references found in the literature search, which had been published since 1995. Most frequently, pseudoaneurysms of knitted polyester prostheses at the femoro-popliteal segment occurred after approximately 12.9 years in average. In one third of cases, two or more non-anastomotic aneurysms of Dacron prostheses were described. Histological and electron-microscopic investigations revealed mainly breakings of filaments and foreign body reactions. In more than half of the patients, the non-anastomotic aneurysm was resected and for reconstruction, a novel vascular prosthesis used as inter-positioned vascular segment was implanted. Complete removal of the prosthesis and endovascular therapy were only 2 nd choice.

Conclusion: Development of prosthetic non-anastomotic aneurysms has not been satisfyingly clarified yet. It belongs to the late complication profile even it occurs rarely - and should be controlled after a postoperative interval of approximately one decade if the arterial recanalization/reconstruction was performed using prosthetic material after previously - in the sequential approach - endovascular intervention and venous bypass could not be used.

\section{Introduction}

In long-term use of Dacron vascular grafts in the periphery, degeneration of the prosthetic material is possible. Reasons can be multifactorial: hydrolysis, erosion, clamping or damage during the manufacturing process ${ }^{14}$.

In rare cases, this can lead to prosthetic non-anastomotic aneurysms with the following complications such as a rupture or a bypass occlusion by thrombus migration.

By means of the following compact mini review, the long-term use of Dacron bypass with the complication of a non-anastomotic aneurysm and its appropriate therapy will be presented along with the analysis of the relevant literature since 1995. 


\section{Material and methods}

On the occasion of the scientific compact review, a systematic literature search was carried out from 1995 to 2016 in PubMed $^{\circledR}$ under the terms:

-aneurysm
-Dacron,
-polyester,
-graft.

This resulted in 321 sources. In addition, a hand search in the bibliography of the selected publications was performed.

Priority was given to English and German publications on aneurysms of polyester prostheses, which were used in the peripheral area (femoro-popliteal, axillo-femoral or prosthetic limb of aortobifemoral bypasses). Studies were excluded that reported aneurysms in aortic and native vessels. Due to the rarity of the prosthetic aneurysms, case reports and retrospective studies were favored, so that a total of 20 publications on non-anastomotic aneurysms in peripheral aorto-femoral/-bifemoral Dacron prostheses were finally included in the review.

Epidemiological, medical history, clinical, (differential) diagnostic, therapeutic, early-postoperative "outcome" characteristics, morphological and histological data as well as "follow up"-based, recorded prognostic aspects were considered. A total of 32 cases of prosthetic aneurysms ( $n=31$ patients) were elucidated.

The statistical analysis was carried out in the recording of the absolute and percentage frequencies of the characteristics as well as mean time of the prostheses in situ until the reliable proof of an aneurysm.

\section{Results (extracted key points from the literature) and discussion}

The statistical analysis of the literature supports the results of other studies. Structural changes of the fibers in the form of filament alterations of various kinds were described in 11 cases, resulting in a pseudoaneurysm. Knitted polyester prostheses with single velour and double velour properties were at the forefront of aneurysm formation. The importance of foreign body giant cells and inflammatory cells has been reported in 6 publications ${ }^{6,10}$,
13,16,20,22. The occurrence of 2 ruptures in the "guideline"7,16 seems to confirm the theory of weaknesses in this guideline of Dieval et al. ${ }^{4}$. The location of the aneurysms varies, most

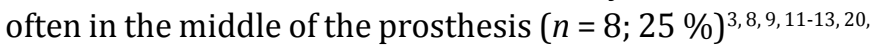
${ }^{21}$, which is actually not a typical clamping area.

A prosthesis in the thigh area, such as the native femoral artery, is subject to particular mechanical stress when anatomically implanted. The influence of external compression due to strong musculature and the fibrous aponeurosis of the adductor canal affecting the superficial femoral artery crossing as already been identified as the cause of restenosis of stents in the superficial femoral artery ${ }^{15}$. This complex mechanical stress could explain the accumulation of prosthesis degeneration in the femoropopliteal area.

The number of surgical revisions at the bypasses $(n=$ $7 ; 21.9 \%)^{1,7,10,16,20,21}$ also indicate an iatrogenic influence of the aneurysm formation, as Miyake et $a l .^{10}$ postulated in their publication.

The reconstruction possibilities of non-anastomotic aneurysms in Dacron prostheses range from complete removal and new creation through resection to interventional and endovascular therapies. In the majority of cases, the corresponding aneurysm was resected and replaced with a new Dacron prosthesis.

Also, the complete removal of the Dacron prosthesis with subsequent implantation of a new bypass enjoys its importance, as in the damaged prosthesis, the formation of further aneurysms is likely, and the patient can be prevented from further recurrent interventions. The surgical effort with potential complications such as blood loss and soft tissue trauma is significantly higher.

The endovascular repair of the aneurysms also provides an elegant and patient-friendly alternative. In the researched cases $^{2,11}$, a Talent ${ }^{\circledR}$ stent-graft prosthesis (Medtronic, Minneapolis / MN, USA) was used. Offer et al. ${ }^{11}$ used a $16 \times 130 \mathrm{~mm}$ stent-graft, which was placed into the native femoral artery with a 22-Fr. introducer after arteriotomy. The oversizing was calculated with $15 \%$, so the aneurysm was excluded without endo-leak. In the case of Alexandrescu et al. ${ }^{2}$, the aneurysm was successfully sealed with a tapered aorto-uni-iliac $24 \times 14 \mathrm{~mm}$ stent graft due to an isolation and punctuation of the femoral artery.

\begin{tabular}{|l|l|l|l|}
\hline Author/Year & Kind of prosthesis & Localization & Therapy \\
\hline $\begin{array}{l}\text { Orii et al. (13) } \\
\text { (1995) }\end{array}$ & $\begin{array}{l}\text { Knitted Dacron, } \\
\text { velour, ringed, } \\
\text { femoro-popliteal }\end{array}$ & $\begin{array}{l}\text { Middle segment of the } \\
\text { prosthesis }\end{array}$ & $\begin{array}{l}\text { Resection of the aneurysm \& ilio- } \\
\text { popliteal knitted } \\
\text { Dacron-bypass }\end{array}$ \\
\hline $\begin{array}{l}\text { Abu Rahma et De Luca (1) } \\
\text { (1995) }\end{array}$ & $\begin{array}{l}\text { Knitted Dacron, } \\
\text { velour, ringed, } \\
\text { femoro-popliteal }\end{array}$ & $\begin{array}{l}2 \mathrm{~cm} \text { above the } \\
\text { popliteal } \\
\text { anastomosis }\end{array}$ & $\begin{array}{l}\text { Resection of the prosthesis, } \\
\text { replacement by PTFE }\end{array}$ \\
\hline
\end{tabular}




\begin{tabular}{|c|c|c|c|}
\hline \multirow[t]{3}{*}{$\begin{array}{l}\text { Vrancken Peeters et al. (21) } \\
\text { (1996) }\end{array}$} & $\begin{array}{l}\text { Knitted Dacron, } \\
\text { femoro-popliteal }\end{array}$ & middle of the prosthesis & Dacron interponate \\
\hline & $\begin{array}{l}\text { Knitted Dacron, } \\
\text { femoro-popliteal }\end{array}$ & $\begin{array}{l}5 \mathrm{~cm} \text { distal from the } \\
\text { proximal anastomosis }\end{array}$ & Dacron interponate \\
\hline & $\begin{array}{l}\text { Knitted Dacron, } \\
\text { femoro-popliteal }\end{array}$ & $\begin{array}{l}\text { Middle segment of the } \\
\text { prosthesis }\end{array}$ & Replacment of the bypass \\
\hline $\begin{array}{l}\text { Irace et al. (6) } \\
\text { (1999) }\end{array}$ & $\begin{array}{l}\text { Knitted Polyester, } \\
\text { aorto-bifemoral }\end{array}$ & Right prosthetic branch & Dacron interponate \\
\hline \multirow[t]{2}{*}{$\begin{array}{l}\text { Arvanitis et al. (3) } \\
(2001)\end{array}$} & $\begin{array}{l}\text { Knitted Dacron, double-velour, } \\
\text { femoro-popliteal }\end{array}$ & $\begin{array}{l}\text { Middle third } \\
\text { of the right thigh }\end{array}$ & $\begin{array}{l}\text { Removal of the prosthesis, } \\
\text { replacement with PTFE }\end{array}$ \\
\hline & $\begin{array}{l}\text { Knitted Dacron, } \\
\text { femoro-popliteal }\end{array}$ & $\begin{array}{l}10 \mathrm{~cm} \text { below the } \\
\text { proximal anastomosis }\end{array}$ & Dacron interponate \\
\hline $\begin{array}{l}\text { Ofer et al. (11) } \\
(2001)\end{array}$ & $\begin{array}{l}\text { Dacron, } \\
\text { aorto-bifemoral }\end{array}$ & $\begin{array}{l}\text { middle left } \\
\text { prosthetic leg }\end{array}$ & Stent graft \\
\hline $\begin{array}{l}\text { Illuminati et al. (5) } \\
\text { (2001) }\end{array}$ & $\begin{array}{l}\text { Dacron, } \\
\text { aorto-bifemoral }\end{array}$ & $\begin{array}{l}\text { Above the femoral } \\
\text { anastomosis }\end{array}$ & PTFE interponate \\
\hline $\begin{array}{l}\text { Khaira et Vohra }(8,9) \\
(2001 / 2002)\end{array}$ & $\begin{array}{l}\text { Knitted Dacron, } \\
\text { femoro-popliteal }\end{array}$ & $\begin{array}{l}\text { Middle segment of the } \\
\text { prosthesis }\end{array}$ & Dacron interponate \\
\hline $\begin{array}{l}\text { Opsommer et Fastrez (12) } \\
\text { (2002) }\end{array}$ & $\begin{array}{l}\text { Knitted Dacron, } \\
\text { iliaco-femoral }\end{array}$ & $\begin{array}{l}\text { Middle segment of the } \\
\text { prosthesis }\end{array}$ & Dacron interponate \\
\hline $\begin{array}{l}\text { Shingu et al. (17) } \\
(2005)\end{array}$ & $\begin{array}{l}\text { Knitted Dacron, } \\
\text { aorto-bifemoral }\end{array}$ & Both prosthetic branches & Dacron interponate \\
\hline Van Damme et al. (20) (2005) & $\begin{array}{l}5 x \text { Knitted Dacron, doubles velour, } \\
1 \times \text { Woven-Knitted } \\
\text { Dacron, } \\
4 \times \text { femoro-popliteal, } \\
1 x \text { femoro-femoral, } \\
1 \times \text { aorto bifemoral }\end{array}$ & $\begin{array}{l}\text { Middle segemtn of the thigh, } \\
\text { supra pubic, } \\
\text { right lower quadrant of the } \\
\text { abdomen }\end{array}$ & $\begin{array}{l}2 x \text { partial removal, } 4 x \text { complete } \\
\text { removal }\end{array}$ \\
\hline Alexandrescu et al. (2) (2008) & $\begin{array}{l}\text { Dacron } \\
\text { aorto-bifemoral }\end{array}$ & Right prosthetic branch & Stent graft \\
\hline $\begin{array}{l}\text { Ryogo et al. (16) } \\
\text { (2011) }\end{array}$ & $\begin{array}{l}\text { Knitted Dacron, } \\
\text { doubles velour, } \\
\text { aorto-bifemoral }\end{array}$ & Left prosthetic branch & ePTFE interponate \\
\hline Shirashi et al. $(18,19)(2012)$ & $\begin{array}{l}\text { Woven Dacron, } \\
\text { axillo-bifemoral }\end{array}$ & $\begin{array}{l}\text { Below the proximal } \\
\text { anastomosis }\end{array}$ & Dacron interponate \\
\hline $\begin{array}{l}\text { Kawajiri et al. (7) } \\
(2014)\end{array}$ & $\begin{array}{l}\text { Knitted Polyester, double velour, aorto- } \\
\text { bifemoral }\end{array}$ & Left prosthetic branch & $\begin{array}{l}\text { Ringed and woven Dacron } \\
\text { interponate }\end{array}$ \\
\hline \multirow[t]{7}{*}{$\begin{array}{l}\text { Yamamoto et al (23) } \\
\text { (2014) }\end{array}$} & $\begin{array}{l}\text { Knitted Dacron, } \\
\text { axillo-femoral }\end{array}$ & Chest-abdomen & Complete replacement \\
\hline & $\begin{array}{l}\text { Knitted Dacron, double velour, } \\
\text { subclavio-aortal }\end{array}$ & Thoracic cavity & Complete replacement \\
\hline & $\begin{array}{l}\text { Knitted Dacron, } \\
\text { Single velour, } \\
\text { aorto-femoral }\end{array}$ & Inguinal & Partial Replacement \\
\hline & $\begin{array}{l}\text { Knitted Dacron, double velour, } \\
\text { femoro-popliteal }\end{array}$ & femoral & Complete replacement \\
\hline & $\begin{array}{l}\text { Knitted Dacron, double velour, } \\
\text { femoro-femoral }\end{array}$ & Lower abdomen & Partial replacement \\
\hline & $\begin{array}{l}\text { Knitted } \\
\text { Dacron, double velour, } \\
\text { femoro-femoral }\end{array}$ & Lower Abdomen & Partial replacement \\
\hline & $\begin{array}{l}\text { Knitted } \\
\text { Dacron, double velour, } \\
\text { aorto-iliac }\end{array}$ & Retroperitoneal cavity & Partial replacement \\
\hline $\begin{array}{l}\text { Woźniak et al. (22) } \\
\text { (2016) }\end{array}$ & $\begin{array}{l}\text { Knitted Dacron, } \\
\text { femoro-popliteal }\end{array}$ & Left mid-thigh & Replacement with venous graft \\
\hline $\begin{array}{l}\text { Miyake et al. (10) } \\
\text { (2016) }\end{array}$ & $\begin{array}{l}\text { Ringed Dacron prosthesis, } \\
\text { axillo-bifemoral }\end{array}$ & $\begin{array}{l}\text { Left abdomen } 10 \mathrm{~cm} \text { below the } \\
\text { costal arch }\end{array}$ & ePTFE interponate \\
\hline
\end{tabular}

Table 1: List of complications and derived measures of vascular reconstruction-associated aneurysms (chronological order) 
The type of therapy must certainly be adapted to the condition and comorbidities of the patient. However, in the literature review on the morphological changes of the Dacron prostheses in the long- term run, the explantation of the entire prosthesis and the creation of a new prosthesis seem to be the most appropriate approach. In this context, the exploration effort with a distinct wound area has to be balanced with possible complications (such as hematoma and wound infection). The endovascular procedures with the possibility of therapy under local anesthesia are most suitable for patients with severe comorbidities and high surgical risk. In general, an exact evaluation of a fulllength prosthetic bypass (by means of clinical examination and duplex ultra-sonography, possibly as complementary measures to CT/MR angiography) is recommended after more than 10 years of implantation. Consequently, detected aneurysms should be treated early.

\section{Summary}

Non-anastomotic aneurysms of Dacron-prostheses in the periphery are rare and occur most often after more than 10 years after its previous implantation, so this complication should be seriously considered after this period of time. The cause is usually the formation of a pseudoaneurysm by structural defects in the Dacron "tissue" (such as multiple filament alterations). The complex mechanical stress of bypasses in the femoropopliteal area could explain the accumulation of prosthesis degeneration with formation of prosthetic aneurysms here. Revision surgery and iatrogenic surgery-related influences seem to play rather a minor role. The occurrence of several aneurysms in the structurally weakened Dacron tissue is probable, which should be taken into account in the choice of the reconstruction method. Endovascular therapy offers a patient-friendly alternative, especially in cases of significant comorbidities.

\section{References}

1. Abu Rahma AF, De Luca JA. Multiple nonanastomotic aneurysms in an external velour ringed Dacron femoropopliteal vascular prosthesis. Ann Vasc Surg. 1995; 9(5): 493-496

2. Alexandrescu V, Ngongang C, Coulon M, et al. Large non-anastomotic false aneurysm on dacron aortobifemoral prosthesis solved by endovascular exclusion. Acta Chir Belg. 2008; 108(6): 747-749

3. Arvanitis DP, Georgopoulos SE, Dervisis KI, et al. Late non-anastomotic false aneurysm formation in femoropopliteal polyethylene terephthalate grafts. Int Angiol. 2001; 20(4): 348-350

4. Dieval F, Chakfe N, Wang L, et al. European Group for Research into vascular Grafts: Mechanisms of Rupture of Knitted Polyester Vascular Prothesis: An In vitro Analysis of Virgin Prostheses. Eur J Vasc Endovasc Surg. 2003; 13: 429-436
5. Illuminati G, Bertagni A, Nasti AG, et al. False aneurysm on dacron prosthesis, 20 years after aortofemoral bypass. Ann Chir. 2001; 126(8): 783-785

6. Irace L, Stumpo R, Costa P, et al. Rupture of Dacron aorto-femoral graft. Case report. J Cardiovasc Surg (Torino). 1999; 40(6): 879-881

7. Kawajiri $\mathrm{H}$, Watanabe $\mathrm{T}$, Kanda $\mathrm{K}$, et al. Longitudinal rupturing of a knitted Dacron graft 30 years after its implantation. Interact Cardiovasc Thorac Surg. 2014; 18(6): 861-863

8. Khaira HS, Vohra H. True aneurysm in a femoro-popliteal dacron graft-a case report and literature review. Cardiovasc Surg. 2002; 10(6): 644-646

9. Khaira HS, Vohra H. True aneurysm in a femoro-popliteal dacron graft-a case report and literature review. EJVES Extra. 2001; 1: 65-68

10. Miyake K, Sakagoshi N, Kitabayashi K. Transverse rupture of ringsupported Dacron graft 10 years after axillobifemoral artery bypass: induced by graft deterioration and Fogarty thrombectomy. J Artif Organs. 2016; 19(4): 403-407

11. Ofer A, Nitecki S, Hoffman A, et al. Dacron graft aneurysm treated by endovascular stent-graft. Cardiovasc Intervent Radiol. 2001; 24(1): $60-64$

12. Opsommer JP, Fastrez J. Spontaneous rupture of a Dacron prosthesis. Acta Chir Belg. 2002; 102(2): 141-144

13. Orii M, Shirasugi N, Yamazaki M, et al. Pseudoaneurysm caused by disruption of an externally supported knitted Dacron graft for femoropopliteal bypass. Tokai J Exp Clin Med. 1995; 20(4-6): 241-244

14. Riepe G. Alloplastische Materialien. In: Debus ES, Gross-Fengels W (Hrsg). Operative und interventionelle Gefäßmedizin. SpringerVerlag; Berlin Heidelberg. 2012.

15. Rosenfield K, Schainfeld R, Pieczek A, et al. Restenosis of endovascular stents from stent compression. J Am Coll Cardiol. 1997; 29(2): 328338

16. Ryugo M, Yasugi T, Nagashima M, et al. Pseudoaneurysm in the Left Groin due to Ruptured Knitted Dacron Graft. Ann Vasc Dis. 2011; 4(2): 154-156

17. Shingu Y, Aoki H, Ebuoka N, et al. Late rupture of knitted Dacron graft. Ann Thorac Cardiovasc Surg. 2005; 11(5): 343-345

18. Shiraishi M, Kimura C, Takeuchi T, et al. Late disruption of axillobifemoral bypass graft. Eur J Cardiothorac Surg. 2012; 42(1): 188

19. Shiraishi M, Kimura C, Takeuchi T, et al. Late-Stage disruption of axillobifemoral bypass graft. Ann Thorac Cardiovasc Surg. 2012;18(5): 485-487

20. Van Damme H, Deprez M, Creemers E, et al. Intrinsic structural failure of polyester (Dacron) vascular grafts. A general review. Acta Chir Belg. 2005; 105(3): 249-255

21. Vrancken Peeters MTFD, Voorwinde A, Mac Kaay AJC, et al. Late Rupture of Femoropopliteal Dacron Grafts: a Rare Complication. Eur J Vasc Surg. 1996; 11: 243-246

22. Woźniak W, Olszewski W, Górski G. Electron microscopy study of a vascular prosthesis destructed in vivo reveals fractures in Dacron fibers. Vascular 2016; 24(1): 100-102

23. Yamamoto S, Hoshina K, Kimura H, et al. Clinical analysis of nonanastomotic aneurysms of implanted prosthetic grafts. Surg Today. 2014; 44(10): 1855-1862 